\title{
UJI EFEK HAMBATAN ATORVASTATIN TERHADAP PEMBENTUKAN SKAR HIPERTROFI PADA KELINCI NEW ZEALAND (Kajian terhadap morfologi klinis ketinggian jaringan skar, Scar Elevation Index, kepadatan kolagen, dan ekspresi $V E G F$ )
}

\author{
ANTI-SCAR EFFECT OF ATORVASTATIN ON HYPERTROPHIC SCAR IN THE \\ NEW ZEALAND RABBIT: The study on clinical morphology height of scar tissue, Scar \\ Elevation Index, collagen density and VEGF expression
}

Devi Usdiana Rosyidah, ${ }^{1}$ Indwiani Astuti, ${ }^{2}$ dan Sitarina Widyarini ${ }^{3}$

${ }^{1}$ Bagian Laboratorium Farmakologi Fakultas Kedokteran UMS

${ }^{2}$ Bagian Laboratorium Farmakologi dan terapi Fakultas Kedokteran UGM

${ }^{3}$ Bagian Laboratorium Patologi Anatomi Fakultas Kedokteran Hewan UGM

Korespondensi: dr. Devi Usdiana Rosyidah, M. Sc. Email: devi.rosyidah@gmail.com/dur203@ums.ac.id

\begin{abstract}
ABSTRAK
Skar hipertrofi dan keloid bagian dari jaringan parut patologis yang insiden kejadiannya masih tinggi. Keduanya mengganggu secara estetik, fisiologik, psikologik, dan sering tumbuh kembali setelah pengobatan. Belum ada terapi standar baku emas untuk skar hipertrofi dan keloid. Efek pleiotropik statin berpotensi sebagai anti skar baru. Penelitian ini bertujuan untuk mengetahui efek hambatan pembentukan skar hipertrofi dengan pemberian salep atorvastatin pada model luka skar di telinga kelinci New Zealand. Kelinci New Zealand usia 4-6 bulan $(n=29)$ dilakukan randomisasi kedalam lima kelompok. Setelah aklimatisasi 1 minggu, dilakukan pembuatan luka model skar hipertrofi pada kedua telinga kelinci dengan punch biopsy $(\mathrm{d}=8 \mathrm{~mm})$. Jumlah luka 2 buah di masingmasing telinga kanan dan kiri. Pada hari ke-7 setelah punch biopsy, kelompok I, II, III dioles salep atorvastatin dengan konsentrasi masing-masing $5 \%, 10 \%$, dan $20 \%$. Kelompok IV dioles salep clobetasol propionate $0,05 \%$ sebagai kontrol positif, dan kelompok V dioles dengan basis salep (lanolin vaselin 1:1) sebagai kontrol negatif. Frekuensi pengolesan salep pada luka ditelinga kelinci tersebut 1 kali/hari, dengan lama pengolesan selama 50 hari kedepan. Setiap hari dilakukan pengukuran morfologi klinis ketinggian skar. Pada hari ke 56 setelah punch biopsy, dilakukan penilaian akhir morfologi klinis jaringan skar hipertrofi, kemudian kelinci didekapitasi, diambil jaringan skar hipertrofi kemudian dibuat preparat histologis (HE, Von Gieson) dan imunohistokimia (VEGF). Salep atorvastatin 5\% mampu menghambat pembentukan skar hipertrofi pada telinga kelinci New Zealand dengan nilai median skoring ketinggian jaringan skar sebesar 1(1-3), nilai SEI rata-rata sebesar 1,49 $\pm 0,37 \mathrm{~mm}$, dan nilai ekspresi VEGF sebesar 12,71 $\pm 4,27 \%$. Salep atorvastatin 5\% mempunyai potensi untuk dikembangkan sebagai obat penghambat pembentukan skar hipertrofi baru dengan mekanisme penghambatan terhadap VEGF. Untuk pengembangan obat ini diperlukan penelitian lebih lanjut mengenai kapan waktu yang paling tepat mulai dioleskan salep atorvastatin setelah terjadi luka berisiko terbentuknya skar hipertrofi.
\end{abstract}

Kata kunci: Atorvastatin, skar hipertrofi, VEGF, telinga kelinci.

\section{ABSTRACT}

Incidence of hypertrophic scar and keloid was still high. Both have aesthetically, physiological, psychological disturbing effect, and often grew back after treatment. There was no gold standard therapy for hypertrophic scar and keloid. Statin has pleiotropic effect. One of them as a potential new anti-scarring. This study aims to determine the effect of barrier formation of hypertrophic scars by administering atorvastatin ointment on the model of wound scar on female New Zealand rabbit ears. New Zealand rabbits aged 4-6 months $(n=29)$ conducted randomized into five groups. After 1 week of acclimatization, be making cuts hypertrophic scarring models in rabbit ears with a punch biopsy $(d=8 \mathrm{~mm})$ with a number of wounds 2 pieces in each of the right and left ear. On the 7th day after the punch biopsy, group I, II, III atorvastatin ointment smeared with concentrations respectively 5\%, 10\% and 
20\%. Group IV smeared clobetasol propionate $0.05 \%$ ointment as positive control, and the group V smeared with ointment base (vaseline lanolin 1:1) as a negative control. Frequency smearing ointment on the wound bunny ears 1 time/day, with long basting during the next 50 days. Every day clinical morphology measurements height scarring. On day 56 after the punch biopsy, performed the final assessment of the clinical morphology of scar tissue hypertrophy, then rabbits were decapitated, hypertrophic scar tissue is taken and then made preparations histologic (HE, Von Gieson) and immunohistochemistry (VEGF). Atorvastatin 5\% ointment could inhibit the formation of hypertrophic scar on New Zealand rabbit ears with median value of scoring height of scar tissue by 1 (1-3), SEI average value $1.49 \pm 0.37 \mathrm{~mm}$, and VEGF expression value $12.71 \pm 4.27 \%$. Atorvastatin ointment $5 \%$ is the potential to be developed as a drug to inhibit the formation of new hypertrophic scar by inhibiting VEGF. For the development of this drug, it needs further research on the other inhibition mechanisms of atorvastatin and when the most appropriate time to apply this ointment after the wound being risky to be hypertrophic scar.

Keywords: atorvastatin, hypertrophic scar, VEGF, rabbit ears

\section{PENDAHULUAN}

Skar hipertrofi secara umum merupakan komplikasi dari penanganan tindakan bedah dan luka bakar. Insidennya antara 40\% sampai $70 \%$ dari tindakan bedah dan 91\% akibat luka bakar (Gauglitz et al., 2011). Faktor risiko terjadinya skar hipertrofi, yaitu luka yang mengenai dermis bagian dalam dan inflamasi yang berkepanjangan (Mohammadi et al., 2013; Van Den Veer et al., 2009). Skar Hipertrofi bisa terjadi di seluruh bagian tubuh, namun predileksinya meningkat di bagian sternum, pundak, lengan atas, daun telinga, dan pipi. Kelainan ini bisa diderita oleh laki-laki maupun perempuan (Gregory dan Holly, 2009 ; Xi-Qiao et al., 2008).

Manajemen terapi terkini dari skar hipertrofi termasuk occlusive dressing, terapi penekanan, injeksi kortikosteroid intralesi, bedah beku (cryosurgery), eksisi, terapi radiasi, terapi laser, dan obat topikal (Chen et al., 2012). Terapi topikal menjadi popular karena mudah dalam penggunaan, nyaman, tidak invasif, dan biayanya relatif lebih murah. Namun, belum ada satu pun terapi yang memberikan hasil optimal untuk mengeliminasi atau mencegah pembentukan skar hipertrofi (Zurada et al., 2006). Saat ini, belum ada pengobatan yang menjadi standar emas (gold standart) untuk kedua gangguan tersebut (Shridharani et al., 2010).

Pada skar hipertrofi, mekanisme perbaikan jaringan dan kontrol pengaturan regenerasi telah hilang. Perkembangan jaringan fibrous yang abnormal ini menjadi dilema utama dalam terapi dan bedah plastik karena gangguan penyembuhannya (Wolfram et al., 2009). Skar hipertrofi sering terjadi rekurensi, menyebabkan gangguan psikologis, dan biaya kesehatan yang mahal dalam jangka panjang (Ogawa, 2010;
Rahmani et al., 2013; Penn et al., 2012).

Banyak penelitian dilakukan untuk berusaha memahami mekanisme skar hipertrofi dan pada gilirannya berusaha untuk mencegahnya. Secara klinis skar hipertrofi tampak sebagai tonjolan kulit berwarna merah, keras, menyebabkan sensasi abnormal dan gangguan fungsional (Penn et al., 2012; Shi et al., 2013). Proses ini diatur oleh sitokin dan faktor pertumbuhan seperti transforming growth factor $\beta$ (TGF- $\beta$ ), epidermal growth factor (EGF), fibroblast growth factor (FGF) dan platelet-derived growth factor (PDGF) (Grieb et al., 2011). Wilgus et al. (2008) menambahkan vasculare endothelial growth factor (VEGF) memiliki pengaruh yang kuat pada pembentukan jaringan skar.

Produksi VEGF berlebih merupakan salah satu mekanisme yang mendasari terbentuknya skar hipertrofi (Penn et al., 2012). VEGF dapat mendorong deposisi jaringan skar secara tidak langsung berdasarkan dampaknya pada angiogenesis. Peran VEGF sebagai penghubung antara angiogenesis dan pembentukan skar dengan menstimulasi langsung sel endotel dan fibroblast dermis. Remodeling matriks yang menyertai angiogensis secara tidak langsung menstimulasi produksi jaringan skar (Wilgus et al, 2008).

Salah satu obat penghambat angiogenesis adalah statin (Elewa et al., 2010). Statin menghambat enzim hydroxymethyl glutarylcoenzyme A (HMG-CoA) reductase pada jalur sintesis kolesterol. Belakangan ini, statin telah terbukti memiliki beberapa efek lain, yang disebut sebagai efek pleiotropik (Pushp et al., 2013). Salah satu efek pleiotropik statin adalah antiangiogenik dan efek ini independen dari efek utamanya sebagai penurun kolesterol (Elewa et al., 2010; Pushp et al., 2013). Di antara anggota 
statin yang bersifat lipofilik yaitu atorvastatin (Komatsu et al., 2011). Penelitian oleh Baharara et al., (2012) menunjukkan atorvastatin menghambat angiogenesis inovo pada chorioallantoic membrane (CAM). Dulak dan Jozkowicz (2005) menjelaskan aktivitas anti-angiogenik statin, yaitu dengan menghambat proliferasi, migrasi, dan induksi apoptosis sel endotel. Hambatan sintesis VEGF berkontribusi pada pelemahan angiogenesis, hal ini menunjukkan atorvastatin memungkinkan untuk menjadi alternatif dalam terapi skar (Van Den-Broek et al., 2012).

Skar hipertrofi dan keloid bagian dari jaringan parut patologis yang insiden kejadiannya masih tinggi. Keduanya mengganggu secara estetik, fisiologik, psikologik, dan sering tumbuh kembali setelah pengobatan. Belum ada terapi standar baku emas untuk skar hipertrofi dan keloid. Efek pleiotropik statin berpotensi sebagai anti skar baru. Penelitian ini bertujuan untuk mengetahui efek atorvastatin terhadap hambatan pembentukan skar hipertrofi berdasarkan parameter morfologi klinis ketinggian jaringan skar, scar elevation index (SEI), kepadatan kolagen, dan ekspresi VEGF pada model luka skar di telinga kelinci.

\section{METODE}

Penelitian yang dilakukan merupakan penelitian eksperimen laboratories dengan rancangan post test only with controlled group design. Variabel bebas pemberian atorvastatin, variabel terikat hambatan pembentukan skar hipertrofi dengan parameter morfologi klinis ketinggian jaringan skar, scar elevation index (SEI), kepadatan kolagen, dan ekspresi VEGF.

Penelitian ini menggunakan zat aktif atorvastatin dibuat sediaan salep topikal dengan campuran lanolin vaselin 1:1 (Toker et al., 2009). Kelompok perlakuan dengan salep atorvastatin $5 \%, 10 \%, 20 \%$, kontrol negatif basis salep (lanolin vaselin 1:1) dan kontrol positif menggunakan salep clobetasol propionate $0,05 \%$. Pelarut atorvastatin calsium menggunakan metanol. Hewan uji terdiri dari 30 ekor kelinci betina New Zealand berusia 4-6 bulan. Pewarnaan imunohistokimia VEGF (bs-1313R, Rb $\alpha$ VEGF, bioss, USA).

Alat yang digunakan jangka sorong untuk mengukur morfologi klinis ketinggian skar hipertrofi, kamera digital untuk dokumentasi foto, mikroskop trinokuler olympus CX41 dan olympus DP20 untuk pengambilan foto preparat histologis, dan Image $J$ sofware untuk interpretasi hasil foto preparat histologis dan imunohistokimia.

Kelinci betina New Zealand usia 4-6 bulan $(\mathrm{n}=29)$ dilakukan randomisasi ke dalam lima kelompok. Setelah aklimatisasi 1 minggu, dilakukan anestesi (ketamin dengan dosis 30 $\mathrm{mg} / 100 \mathrm{~g}$ berat badan dan acepromazin $10 \mathrm{mg} / 100$ g berat badan) kemudian dibuat luka model skar hipertrofi pada kedua telinga kelinci dengan punch biopsy (kruuse) diameter $8 \mathrm{~mm}$ dengan jumlah luka 2 buah di masing-masing telinga kanan dan kiri (Saulis et al., 2002; Zhu et al., 2008). Jumlah luka total 116 luka model skar hipertrofi. Luka ditutup dengan poliurethrane dressing (Tegaderm) selama 1 hari. Pada hari ke-7 setelah punch biopsy, kelompok I, II, III dioles salep atorvastatin dengan konsentrasi masing-masing 5\%,10\%, dan 20\%. Kelompok IV dioles salep clobetasol propionate $0,05 \%$ sebagai kontrol positif dan kelompok $\mathrm{V}$ dioles dengan basis salep (lanolin vaselin 1:1) sebagai kontrol negatif. Frekuensi pengolesan salep pada luka di telinga kelinci tersebut 1 kali/ hari, dengan lama pengolesan selama 50 hari ke depan. Setiap hari dilakukan pengukuran morfologi klinis ketinggian skar. Pada hari ke 56 setelah punch biopsy, dilakukan penilaian akhir morfologi klinis jaringan skar hipertrofi, kemudian kelinci didekapitasi, diambil jaringan skar hipertrofi kemudian dibuat preparat histologis (HE, Von Gieson) dan imunohistokimia (VEGF).

Data penelitian berupa nilai rata-rata (mean) dari kecepatan menutupnya luka (satuan hari), volume akhir skar hipertrofi (satuan $\mathrm{mm}^{3}$ ), kepadatan kolagen skar (satuan \%) dan ekspresi VEGF (satuan \%), scar elevation index (SEI) (satuan $\mathrm{mm}$ ) dan nilai tengah (median) dari morfologi klinis ketinggian skar pada masingmasing kelompok. Data hasil pengamatan dilakukan uji normalitas data dengan KolmogorovSmirnov kemudian diuji dengan Kruskal-Wallis dan dilanjutkan dengan uji Mann Whitney. Dari beberapa parameter tersebut ditambah uji korelasi Spearman.

\section{HASIL DAN PEMBAHASAN}

Hasil penelitian berupa waktu menutupnya luka, volume akhir skar hipertrofi, morfologi klinis ketinggian jaringan skar hipertrofi, scar elevation index, kepadatan kolagen, dan ekspresi VEGF dapat dilihat pada tabel berikut. 
Tabel 1 Waktu menutupnya luka setelah tindakan bedah, volume akhir jaringan skar, dan morfologi klinis ketinggian jaringan skar hipertrofi pada telinga kelinci

\begin{tabular}{lccc}
\hline \multicolumn{1}{c}{ Kelompok Perlakuan } & $\begin{array}{c}\text { Waktu menutup luka } \\
\text { (Rata-rata } \pm \text { SD) }\end{array}$ & $\begin{array}{c}\text { Volume akhir skar } \\
\text { (Rata-rata } \pm \text { SD) }\end{array}$ & $\begin{array}{c}\text { Ketinggian jaringan } \\
\text { skar Median (min-max) }\end{array}$ \\
\hline Atorvastatin 5\% & $16,04 \pm 2,69$ & $10,66 \pm 26,06$ & $1(1-3)$ \\
Atorvastatin 10\% & $17,75 \pm 6,27$ & $2,03 \pm 5,95$ & $1(1-2)$ \\
Atorvastatin 20\% & $14,75 \pm 1,21$ & $33,88 \pm 38,59$ & $1(1-3)$ \\
Clobetasol propionate 0,05\% & $16,92 \pm 1,93$ & $0,92 \pm 4,49$ & $0(0-1)$ \\
Lanolin vaselin 1: 1 & $14,83 \pm 2,55$ & $98,75 \pm 165,03$ & $2(1-3)$ \\
\hline
\end{tabular}

Keterangan: skoring ketinggian jaringan skar hipertrofi; $0=$ skar $(-), 1=$ skar $(+)$ palpasi, $2=$ skar $(+)$ inspeksi, $3=$ skar $(+)$ prominen. Hasil tabel di atas dilakukan uji nomalitas data dengan kolmogorov smirnov $(\mathrm{p}<0,05)$ dan uji Kruskal Wallis $(\mathrm{p}<$ $0,05)$.

Tabel 2 Scar elevation index, kepadatan kolagen skar dan ekspresi VEGF jaringan skar pada telinga kelinci

\begin{tabular}{lccc}
\hline \multicolumn{1}{c}{ Kelompok Perlakuan } & $\begin{array}{c}\text { Scar elevation index } \\
(\mathbf{m m}) \text { Rata-rata } \pm \text { SD }\end{array}$ & $\begin{array}{c}\text { Kepadatan kolagen } \\
(\%) \text { Rata-rata } \pm \text { SD }\end{array}$ & $\begin{array}{c}\text { Ekspresi VEGF (\%) } \\
\text { Rata-rata } \pm \text { SD }\end{array}$ \\
\hline Atorvastatin 5\% & $1,49 \pm 0,37$ & $9,74 \pm 2,21$ & $12,71 \pm 4,27$ \\
Atorvastatin 10\% & $1,79 \pm 0,36$ & $10,26 \pm 3,09$ & $16,06 \pm 7,15$ \\
Atorvastatin 20\% & $1,74 \pm 0,39$ & $11,96 \pm 3,43$ & $20,39 \pm 10,00$ \\
Clobetasol propionate 0,05\% & $0,92 \pm 0,37$ & $3,74 \pm 0,89$ & $9,00 \pm 4,92$ \\
Lanolin vaselin 1:1 & $2,06 \pm 1,05$ & $11,37 \pm 6,99$ & $29,61 \pm 10,97$ \\
\hline
\end{tabular}

Keterangan: Hasil tabel di atas dilakukan uji normalitas data dengan kolmogorov smirnov ( $<0,05)$ dan uji Kruskal Wallis (p $<0,05)$.

Tabel 3 Nilai signifikansi ( $p$ ) uji Mann Whitney terhadap waktu menutupnya luka setelah tindakan bedah, volume akhir jaringan skar, dan morfologi klinis ketinggian jaringan skar pada telinga kelinci

\begin{tabular}{lccc}
\hline \multicolumn{1}{c}{ Kelompok Perlakuan } & $\begin{array}{c}\text { Kecepatan } \\
\text { menutup luka }\end{array}$ & $\begin{array}{c}\text { Volume akhir } \\
\text { skar }\end{array}$ & $\begin{array}{c}\text { Ketinggian jaringan } \\
\text { skar hipertrofi }\end{array}$ \\
\hline Atorvastatin 5\% - Atorvastatin 10\% & 0,764 & 0,545 & 0,118 \\
Atorvastatin 5\% - Atorvastatin 20\% & 0,185 & 0,003 & 0,138 \\
Atorvastatin 5\% - Clobetasol propionate 0,05\% & 0,197 & 0,139 & 0,000 \\
Atorvastatin 5\% - Lanolin vaselin 1: 1 & 0,010 & 0,000 & 0,005 \\
Atorvastatin 10\% - Atorvastatin 20 \% & 0,358 & 0,000 & 0,005 \\
Atorvastatin 10\% - Clobetasol propionate 0,05\% & 0,072 & 0,312 & 0,000 \\
Atorvastatin 10\% - Lanolin vaselin 1: 1 & 0,018 & 0,000 & 0,000 \\
Atorvastatin 20 \% - Clobetasol propionate 0,05\% & 0,000 & 0,000 & 0,000 \\
Atorvastatin 20 \% - Lanolin vaselin 1: 1 & 0,181 & 0,028 & 0,196 \\
Clobetasol propionate 0,05\% - Lanolin vaselin 1: 1 & 0,002 & 0,000 & 0,000 \\
\hline
\end{tabular}

Keterangan: *) nilai $\mathrm{p}<0,05$ hasil uji Mann-Whitney pada berbagai kelompok perlakuan.

Tabel 4 Nilai signifikansi ( $p$ ) uji Mann Whitney terhadap scar elevation index, kepadatan kolagen skar, dan ekspresi VEGF jaringan skar pada telinga kelinci

\begin{tabular}{lccc}
\hline \multicolumn{1}{c}{ Kelompok Perlakuan } & $\begin{array}{c}\text { Scar elevation } \\
\text { index }\end{array}$ & $\begin{array}{c}\text { Kepadatan } \\
\text { kolagen }\end{array}$ & Ekspresi VEGF \\
\hline Atorvastatin 5\% - Atorvastatin 10 \% & 0,102 & 0,716 & 0,210 \\
Atorvastatin 5\% - Atorvastatin 20\% & 0,061 & 0,033 & 0,060 \\
Atorvastatin 5\% - Clobetasol propionate 0,05\% & 0,000 & 0,000 & 0,059 \\
Atorvastatin 5\% - Lanolin vaselin 1: 1 & 0,020 & 0,636 & 0,000 \\
Atorvastatin 10\% - Atorvastatin 20\% & 0,927 & 0,153 & 0,394
\end{tabular}


Atorvastatin $10 \%$ - Clobetasol propionate $0,05 \%$

$\begin{array}{lll}0,000 & 0,000 & 0,021 \\ 0,489 & 0,538 & 0,000 \\ 0,000 & 0,000 & 0,004 \\ 0,585 & 0,033 & 0,003 \\ 0,000 & 0,000 & 0,000\end{array}$

Atorvastatin 10\% - Lanolin vaselin 1: 1

Atorvastatin $20 \%$ - Clobetasol propionate $0,05 \%$

Atorvastatin $20 \%$ - Lanolin vaselin 1: 1

0,000

0,000

0,000

Keterangan: *) nilai $\mathrm{p}<0,05$ hasil uji Mann-Whitney pada berbagai kelompok perlakuan.

Tabel 5 Korelasi antar berbagai parameter penelitian

\begin{tabular}{lcccc}
\hline \multicolumn{1}{c}{ Kelompok } & $\begin{array}{c}\text { Nilai } \\
\text { Signifikansi (p) }\end{array}$ & $\begin{array}{c}\text { Koefisien } \\
\text { Spearman }(\mathbf{r})\end{array}$ & Arah Korelasi & $\begin{array}{c}\text { Kekuatan } \\
\text { Korelasi }\end{array}$ \\
\hline Ketinggian jar. SH - SEI *) & 0,000 & 0,436 & positif & Sedang \\
Ketinggian jar. SH - kepadatan kolagen *) & 0,000 & 0,545 & positif & Sedang \\
Ketinggian jar. SH - ekspresi VEGF *) & 0,001 & 0,466 & positif & Sedang \\
Ketinggian jar. SH - kec.penutupan luka *) & 0,033 & $-0,198$ & negatif & Sangat lemah \\
Ketinggian jar. SH - volume akhir SH *) & 0,000 & 0,760 & positif & Kuat \\
SEI - kepadatan kolagen *) & 0,000 & 0,464 & positif & Sedang \\
SEI - ekspresi VEGF *) & 0,002 & 0,423 & positif & Sedang \\
SEI - kec.penutupan luka & 0,198 & $-0,128$ & negatif & Sangat lemah \\
SEI - volume akhir SH *) & 0,004 & 0,281 & positif & Lemah \\
Kepadatan kolagen - ekpresi VEGF & 0,276 & 0,156 & positif & Sangat lemah \\
Kepadatan kolagen - kec.penutupan luka & 0,156 & $-0,143$ & negatif & Sangat lemah \\
Kepadatan kolagen - volume akhir SH *) & 0,002 & 0,301 & positif & Lemah \\
Ekpresi VEGF - kec.penutupan luka & 0,218 & $-0,175$ & negatif & Sangat lemah \\
Ekpresi VEGF - volume akhir SH *) & 0,010 & 0,360 & positif & Lemah \\
kec.penutupan luka - volume akhir SH & 0,011 & $-0,236$ & negatif & Lemah \\
\hline
\end{tabular}

Keterangan: *) nilai $\mathrm{p}<0,05$ dengan uji korelasi Spearman, setelah dilakukan uji normalitas data dengan KolmogorovSmirnov $(\mathrm{p}<0,05)$

Penelitian ini menggunakan atorvastatin berbentuk salep. Atorvastatin murni didapatkan dari hibah dengan spesifikasi zat aktif dapat dilihat pada lampiran 2. Sediaan salep atorvastatin dibuat dengan cara yang sesuai dengan metode pembuatan salep yang baik dan sudah dilakukan uji farmasetik. Atorvastatin bersifat lipofilik (Brookes et al, 2009). Basis salep menggunakan lanolin dan vaselin yang memiliki sifat minyak. Salep atorvastatin yang digunakan ada 3 variasi dosis yaitu salep atorvastatin 5\%, salep atorvastatin $10 \%$, dan salep atorvastatin $20 \%$.

Data kecepatan menutupnya luka model skar hipertrofi (Tabel 1) menunjukkan waktu tercepat luka menutup pada hari ke 14 (kontrol positif) setelah pembuatan luka dengan punch biopsy. Pada luka biasa proses regenerasi lengkap epidermis kelinci akan selesai pada hari ke 6 setelah perlukaan (Alfars, 2009). Hal ini menunjukkan luka yang dalam dengan hilangnya epidermis sampai ke dermis (punch biopsy) membuat proses penutupan luka menjadi lebih lama dibanding luka biasa. Kelompok perlakuan dengan salep atorvastatin 5\% dan kelompok kontrol positif (clobetasol propionate 0,05\%) kecepatan menutupnya luka lebih terlambat (hari ke 16) dibanding kelompok kontrol positif (hari ke 14). Mekanisme luka model skar hipertrofi adalah proses pemanjangan inflamasi di samping mekanisme angiogenesis berlebihan. Pemberian atorvastatin memungkinkan terjadi hambatan proses inflamasi sehingga menghambat penutupan luka. Hal ini sejalan dengan penelitian Araujo et al. (2010) yang menyebutkan pemberian atorvastatin dapat menghambat proses inflamasi. Clobetasol propionate $0,05 \%$ merupakan salah satu kortikosteroid topikal potensi tinggi (Kwok dan Rao, 2011). Salah satu penyebab terganggunya proses penyembuhan luka adalah hambatan fase inflamasi akibat pemberian steroid.

Skar hipertrofi merupakan efek dari luka yang mengenai dermis pada kulit (Van den broek 
et al., (2012). Patogenesis dari SH adalah produksi berlebih dari fibroblast dan deposisi kolagen yang eksesif (Shi et al., 2013). Gambaran klinis SH yaitu skar berwarna merah, menonjol, dan masanya tidak melebihi batas luka (Chen et al., 2012). Parameter morfologi klinis ketinggian jaringan skar hipertrofi lebih rendah secara signifikan pada kelompok atorvastatin $5 \%$, atorvastatin $10 \%$, dan kontrol positif dibandingkan dengan kontrol negatif (Tabel 1). Parameter scar elevation index (SEI) hanya pada kelompok atorvastatin 5\% didapatkan nilai SEI lebih rendah secara signifikan dibandingkan dengan kontrol negatif, tetapi lebih tinggi secara signifikan dibandingkan dengan kontrol positif (Tabel 2).

Morfologi klinis ketinggian jaringan skar yaitu menilai secara makroskopis tingginya skar hipertrofi dari permukaan kulit telinga kelinci yang sebelumnya dibuat luka dengan punch biopsy. SEI menilai indeks peninggian skar secara mikroskopis. Morfologi klinis ketinggian jaringan skar maupun SEI keduanya menilai ketebalan dermis dan epidermis dari skar hipertrofi. Hasil ini mendukung penelitian Van den broek et al. (2012) yang menyebutkan atorvastatin dapat menurunkan ketebalan epidermis dan dermis secara in vitro.

Hasil pengukuran SEI pada kelompok clobetasol propionate, ditemukan angka yang paling kecil. Hal ini menunjukkan potensi clobetasol propionate sangat baik dalam menghambat pembentukan skar hipertrofi dibanding kelompok perlakuan lain. Namun, clobetasol memiliki efek samping yang merugikan untuk penggunaan jangka panjang. Jalali dan Bayat (2007) menyebutkan kortikosteroid digunakan untuk manajemen terapi skar yang abnormal, namun pemakaiannya dalam jangka panjang berkaitan dengan berbagai macam efek yang merugikan.

Parameter kepadatan kolagen skar (Tabel 2) menunjukkan kelompok atorvastatin 5\% didapatkan hasil yang paling rendah di antara kelompok atorvastatin yang lain, meskipun secara statistik tidak berbeda signifikan. Van den broek et al. (2012) menyebutkan penelitian in vitro atorvastatin mampu menurunkan proliferasi fibroblast dan produksi kolagen. An et al., (2013) pada penelitian in vivo dengan tikus menjelaskan, atorvastatin dapat menghambat proliferasi fibroblast dan meningkatkan degradasi kolagen pada fibrosis miokardial. Kepadatan kolagen kelompok clobetasol propionate menunjukkan angka terkecil. Kwok dan Rao (2011) menjelaskan mekanisme kerja kortikosteroid yaitu menekan respons imun, mengurangi sintesis kolagen, menghambat fibroblast, dan meningkatkan degenerasi kolagen dari skar hipertrofi. Hasil statistik kepadatan kolagen yang tidak signifikan ini menurut peneliti berkaitan dengan intensitas hasil pewarnaan Von Gieson yang cukup banyak variasi dari warna merah muda terang sampai merah muda kuat. Perbedaan warna ini terjadi karena pewarnaan preparat Von Gieson pada penelitian ini tidak dilakukan dalam satu waktu (dua tahap). Hal ini berkaitan dengan metode pembacaan yang menggunakan fraksi volume Image J sofware, di mana prinsip kerja metode ini berdasarkan intensitas gelap terang dari objek foto preparat.

Parameter ekspresi VEGF (Tabel 2) kelompok atorvastatin 5\%, atorvastatin $10 \%$, dan atorvastatin $20 \%$ lebih rendah secara bermakna dibandingkan dengan kelompok kontrol negatif. Hal ini menunjukkan mekanisme atorvastatin dalam menghambat pembentukan skar hipertrofi pada telinga kelinci melalui jalur hambatan terhadap VEGF. Wilgus et al. (2008) menyebutkan faktor pertumbuhan yang berperan dalam mekanisme pembentukan $\mathrm{SH}$ salah satunya adalah VEGF. VEGF dapat mendorong deposisi jaringan skar secara tidak langsung berdasarkan dampaknya pada angiogenesis. Saat menjalani angiogenesis, sel endotel dermal bisa menghasilkan sejumlah besar TGF- $\beta$, CTGF, atau faktor profibrotik lainnya, merangsang produksi jaringan skar berikutnya oleh fibroblast didekatnya. Remodeling matrik yang menyertai angiogenesis secara tidak langsung menstimulasi produksi jaringan skar. Hal ini memungkinkan bahwa VEGF sendiri dapat bertindak sebagai penghubung antara angiogenesis dan pembentukan skar dengan menstimulasi langsung sel endotel dan fibroblast dermis.

Pada penelitian ini ekspresi VEGF dapat ditemukan pada sel endotel dan sel fibroblast jaringan skar hipertrofi. Hal ini sesuai dengan Van der Veer et al. (2009) yang menyebutkan selsel yang mengekspresikan VEGF pada jaringan skar antara lain sel makrofag, sel keratinosit, sel endotel, dan sel fibroblast. Xi-Qiao et al. (2009) dalam penelitiannya menjelaskan ekspresi sitokin TGF- $\beta 1$, VEGF, PDGF, ET-1, dan bFGF 
pada jaringan skar hipertrofi manusia lebih kuat dibandingkan jaringan kulit normal dengan pewarnaan imunohistokimia. Distribusi dari sitokin-sitokin tersebut nampak pada sitoplasma fibroblast dan matriks ekstraseluler. Xi-Qiao et al. juga menjelaskan sekresi sitokin VEGF oleh sel fibroblast jaringan skar secara dramatis lebih tinggi dibandingkan sekresi VEGF oleh sel endotel jaringan skar hipertrofi pada kultur sel. Cao et al., (2014) menambahkan pada awal pembentukan skar hipertrofi ekspresi VEGF pada lapisan basal dari epidermis meningkat secara signifikan dibandingkan kulit normal. Pematangan skar hipertrofi menyebabkan ekspresi VEGF secara gradual akan menurun sampai nampak seperti ekspresi VEGF pada kulit normal.

Hasil uji korelasi antar parameter penelitian morfologi klinis ketinggian jaringan skar, scar elevation index, kepadatan kolagen, dan ekspresi VEGF menunjukkan arah korelasi positif (Tabel 5), kecuali korelasi dengan kecepatan penutupan luka yang menunjukkan arah negatif. Hasil tersebut secara umum menunjukkan semakin rendah ketinggian jaringan skar hipertrofi, semakin rendah pula nilai scar elevation index, semakin rendah kepadatan kolagennya, dan semakin sedikit ekspresi VEGF-nya. Makna korelasi negatif dari kecepatan menutupnya luka dengan volume akhir skar hipertrofi yang terbentuk menunjukkan bahwa semakin cepat luka menutup, maka volume skar hipertrofi yang terbentuk semakin besar. Begitu juga sebaliknya, apabila luka semakin lama menutup, maka volume skar hipertrofi yang terbentuk semakin kecil. Pada penelitian ini mekanisme neovaskularisasi berlebih lebih dominan dalam pembentukan skar hipertrofi dibanding kecepatan penutupan luka. Proses neovaskularisasi berlebih ini sejalan dengan hasil parameter ekspresi VEGF. Hal ini dikuatkan oleh Xi-qiao et al. (2009) yang menyebutkan bahwa ekspresi berlebih VEGF oleh sel fibroblast dari jaringan skar hipertrofi menyebabkan proliferasi fibroblast dan mendukung pembentukan pembuluh darah mikro (neovaskularisasi). Secara klinis dapat dijelaskan meskipun luka telah menutup, volume skar hipertrofi yang terbentuk masih bertambah sampai akhir penelitian.

\section{SIMPULAN DAN SARAN}

Berdasarkan hasil penelitian didapatkan morfologi klinis ketinggian jaringan skar, scar elevation index dan ekspresi VEGF dengan pemberian salep atorvastatin 5\% lebih rendah secara signifikan dibanding kontrol negatif. Namun, potensi hambatan atorvastatin terhadap pembentukan skar hipertrofi lebih lemah dibanding kontrol positif pada model luka skar di telinga kelinci New Zealand.

Saran untuk pengembangan penelitian, dilakukan penelitian lanjutan untuk melihat pada hari keberapa sebaiknya salep atorvastatin mulai diberikan setelah pembedahan, agar mendapatkan efek hambatan pembentukan skar hipertrofi yang maksimal.

\section{DAFTAR PUSTAKA}

Alfars, A. A. 2009. Histological Study Of Early Events During Wound Healing in Rabbits. Bas.J.Vet. Res. 8 (1)

An, Z., Yang, G, He. YQ., Dong, N. G. L. L., Li, S. M., \& Zhang, W. Q. 2013. Atorvastatin Reduces Myocardial Fibrosis in a Rat Model With Post-Myocardial Infarction Heart Failure by Increasing the Matrix Metalloproteinase-2/Tissue Matrix Metalloproteinase Inhibitor-2 Ratio. Chin Med J (Engl). 126 (11):2149-56.

Araújo, F. A., Rocha, M. A., Mendes, J. B., Andrade, S. P., 2010. Atorvastatin Inhibits Inflammatory Angiogenesis in Mice Through Down Regulation of VEGF, TNF-alpha and TGF-beta1. Biomed Pharmacother. 64 (1): 29-34.

Baharara, J., Zafar-Balanezhad, S., Nejad-Shahrokhabadi, K., \& Hesami, Z., 2012. The Effects of Different Doses of Atorvastatin on Angiogenesis of Chorioallantoic Membrane of Chick Embryo. J Sharekord Univ Med Sci. 14 (2): 12-19.

Brookes, Z. L. S., McGown, C. C. \& Reilly, C. S. 2009. Statins for All: the New Premed? Br J Anaesth. 103 (1): 99-107.

Chao, P-F., Xu, Y-B., Tang, J-M., Yang, R-H.,\&Liu, X-S. 2014. HOAX9 Regulates Angiogenesis in 
Human Hypertrophic Scar: Induction of Vegf Secretion by Epidermal Stem Cells. Int J Clin Exp Pathol.7(6):2998-3007

Chen, X., Peng, L., \& Gao, J., 2012. Novel Topical Drug Delivery Systems and Their Potential Use in Scars Treatment. Asian J. Pharm Sci. 7(3): 155-167.

Dulak, J., \& Józkowicz, A., 2005. Anti-Angiogenic and Anti-Inflammatory Effects of Statins: Relevance to Anti-Cancer Therapy. Curr Cancer Drug Targets. 5(8): 579-594.

Elewa, H. F., El-Remessy, A. B., SSomanath, P R., Fagan, S. C., 2010. Diverse Effect of Statins on Angiogenesis: New Therapeutic Avenues. Pharmacotheraphy. 30 (2):169-176

Gauglitz, G. G., Korting H. C., Pavicic T., Ruzicka T., \& Jeschke M. G., 2011. Hypertrophic Scarring and Keloids: Pathomechanisms and Current and Emerging Treatment Strategies. Mol Med. 17 (1-2): 113-125.

Gregory, J., dan Holly, H-A. 2009. Management of Keloids and Hypertrophic Scars. Am Fam Physician. 80 (3): 253-60.

Grieb, G., Steffens, G., Pallua, N., Bernhagen, J., Bucala, R., 2011. Circulating Fibrocytes-Biology and Mechanisms in Wound Healing and Scar Formation. Int Rev Cell Mol Biol. 291: 1-19.

Jalali, M \& Bayat, A. 2007. Steroids are Used Therapeutically in the Management of Abnormal Scars; However, This is Associated with a Variety of Adverse Effects. Surgeon. 5(3):175-80.

Komatsu, T., Tachibana, H., Sato, Y., Ozawa, M., Kunugita, F., \& Nakamura, M., 2011. Long-term Efficacy of Upstream Therapy with Lipophilic or Hydrophilic Statins on Antiarrhythmic Drugs in Patients with Paroxysmal Atrial Fibrillation. Comparison between Atorvastatin and Pravastatin. Int Heart J. 52:359-365.

Kwok, T., dan Rao, J. 2011. A Practical Approach to Classification and Treatment of Scars. http://www. skintherapyletter.com/fp/2011/7.6/3.html

Mohammadi, A. A., Panah, M. M., Pakyari, M. R., Tavakol, R., Ahrary, I., Jafari, S. M. S., \& Sharifian, M., 2013. Surgical Excision Followed by Low Dose Rate Radiotherapy in the Management of Resistant Keloids. World J Plast Surg. 2 (2): 81-86.

Ogawa, R., 2010. The Most Current Algorithms for the Treatment and Prevention of Hypertrophic Scars and Keloids. Plast. Reconstr. Surg. 125: 557-568.

Penn, J. W., Adriaan O. G., \& Kerstin J. R., 2012. The Role of the tgf- $\beta$ Family in Wound Healing, Burns and Scarring: a Review Article. Int J Burn Trauma. 2 (1): 18-28.

Pushp, P., Patnaik, L., Sharma, N., Lee, H. T., \& Gupta, M. K., 2013. Emerging Role of Statins in Tissue Engineering and Therapeutics-a Review. J. Animal Research. 3 (1): 1-15.

Rahmani, N., Hashemi, S. A., \& Ehteshami, S., 2013. Vitamin E and its Clinical Challenges in Cosmetic and Reconstructive Medicine with Focus on Scars; a Review. Review Article. J Pak Med Assoc. 63 (3): 380-2.

Saulis, A. S., Chao, J. D., Telser, A., Mogford, J. E., \& Mustoe, T. A., 2002. Silicone Occlusive Treatment of Hypertrophic Scar in the Rabbit Model. Aesthetic Surg J. 22 (2): 147-153.

Shi, H-X., Lin, C., Lin, B-B., Wang, Z-G., Zhang, H-Y., et al., 2013. The Anti-scar Effects of Basic Fibroblast Growth Factor on the Wound Repair in vitro and in vivo. PLoS ONE. 8(4): e59966.

Shridharani, S. M., Michael M., Paul N. M., Navin K. S., Basak B., \& Gedge D. R., 2010. The Emerging Role of Antineoplastic Agents in the Treatment of Keloids and Hypertrophic Scars. A review. Ann Plast Surg. 64 (3): 355-361.

Toker, S., Gulcan, E., Cayc, M. K., Olgun, E. G., Erbilen, E., \& Ozay, Y., 2009. Topical Atorvastatin in the Treatment of Diabetic Wounds. Am J Med Sci. 338 (3): 201-4.

Van Den-Broek, L. J., Niessen, F. B., Scheper, R. J., \& Gibbs, S., 2012. Development, Validation, and Testing of a Human Tissue Engineered Hypertrophic Scar Model. Altex. 29 (4/12): 389-402. 
Van der veer, W, M., Bloemen, M. C. T., Ulrich, M. M. W., Molema, G., Van Zuijlen, P. P., Middlekoop, E., \& Niessen, F. B., 2009. Potential Cellular and Molecular Causes of Hypertrophic Scar Formation. Burn. 35: 15-29.

Wilgus, T. A., Ferreira, A. M., Oberyszyn, T. M., Bergda, V. K., \& DiPietro, L. A., 2008. Regulation of Scar Formation by Vascular Endothelial Growth Factor. Lab Invest. 88 (6): 579-590.

Wolfram, D., Tzankov, A., PuLzl, P., \& Piza-Katzer, H., 2009. Hypertrophic Scars and Keloids-Review of Their Pathophysiology, Risk Factors, and Therapeutic Management. Review article. Dermatol Surg. 35:171-181.

Xi-Qiao, W., Liu, Y. K., Wang, Z. Y., Wei, J., Jiang, Y. Z., Qing, C., \& Lu, S. L., 2008. Antimitotic Drug Injections and Radiotherapy: a Review of the Effectiveness of Treatment for Hypertrophic Scars and Keloids. Int J Low Extrem Wounds. 7 (3): 151-159.

Xi-Qiao, W., Ying-Kai, L., Chun, Q., \& Shu-Liang, L., 2009. Hyperactivity of Fibroblasts and Functional Regression of Endothelial Cells Contribute to Microvessel Occlusion in Hypertrophic Scarring. Microvasc Res. 77: 204-211.

Zhu, G. Y., Xu, B., \& Cai, J. L., 2008. Experimental Research of Correlation between Anatomy Structure of Rabbit Ear and Creating Hypertrophic Scar Animal Model. Article in Chinese. Zhonghua Zheng Xing Wai Ke Za Zhi. 24 (3): 216-9.

Zurada, J. M., Kriegel, D., \& Davis, I. C., 2006. Topical Treatment for Hypertrophic Scars. J Am Acad Dermatol. 55 (6): 1024-31 